\title{
The Characteristics and Financing of SMEs in China
}

\author{
Xiaolong Liu* \\ School of Finance and Public Management \\ Yunnan University of Finance and Economics \\ Kunming, China \\ 1113196591@qq.com
}

\author{
Quanping Kuang \\ Institute of Economic Research \\ Yunnan University of Finance and Economics \\ Kunming, China \\ 704802558@qq.com
}

\begin{abstract}
Since the reform of the market economy system was implemented in our country, China's small and mediumsized enterprises have developed at a rapid pace, which has contributed to China's economic development and cannot be ignored. However, many problems such as financing difficulties have severely limited the development of SMEs. SMEs are unable to expand their production scale and complete production in a timely manner despite the lack of self-owned funds and poor external financing. Even in the face of good development opportunities in the market, SMEs can easily cause the slow development or even closure of SMEs in China. With the gradual deepening of China's economic system reform, how to help SMEs to solve financing problems has become a common problem that cannot be avoided by both governments and enterprises.
\end{abstract}

Keywords—microfinance companies; SMEs; financing

\section{INTRODUCTION}

According to statistics from the State Administration of Industry and Commerce, in recent years, the number of small and medium-sized enterprises established in China has rapidly increased. This not only brings new vitality to China's economic development, but in addition, SMEs can provide a large number of jobs, which also alleviates the difficulty of employment in China to some extent. To contribute to the social stability of our country. In recent years, the business scope of SMEs has gradually expanded, which can provide diversified product services, thus greatly satisfying the rich economic needs of our people. However, although there are a large number of newly registered small and medium-sized enterprises each year, there are also a large number of small and medium-sized enterprises who are "dead" at the same time they emerge[1].Why is the survival rate of SMEs in China so low? This has a lot to do with the SMEs themselves. In the early days of the establishment of small and medium-sized enterprises in China, most businesses were small in size. The founders lacked long-term business vision and failed to formulate long-term development plans based on market demand.

On the other hand, SME operators lacked sensitivity to economic markets, and products could not be replaced in a timely manner. The lack of innovative spirit is easily eliminated in today's highly competitive market environment.
Apart from the problems of SMEs themselves, the issue of financing difficulties for SMEs has been accompanied by its development since the "birth" of SMEs. The initial stage of the establishment of small and medium-sized enterprises is small. If it is necessary to expand the scale of operation, it will inevitably require the purchase of equipment. In this way, SMEs have strong financing needs.

Bank loans dominate the SME financing process. However, due to the aforementioned, SMEs have a small initial operating scale and lack collateral for collateral; due to the imperfect credit evaluation system, information exists between banks and SMEs. Asymmetry, it is prone to credit disputes, which makes it difficult for SMEs to raise funds from banks. Although in recent years, China has actively developed new three boards, the purpose is to solve the problem of financing difficulties for SMEs, but due to the initial stage of the development of the GEM, it is also difficult for SMEs to "get the urgency"[2]. Many SMEs will also turn to private capital markets to borrow funds. However, China's private lending market lacks sound management laws and regulations. In recent years, there have been many vicious credit disputes.

\section{CHARACTERISTICS OF CHINA'S SME DEVELOPMENT}

In the course of China's economic development, SMEs have played a role that cannot be ignored. Since the piloting of SMEs in China in 2008, SMEs in China have developed rapidly. This has aroused the close attention of all sectors of society to SMEs. Through the study of the characteristics of the size and quantity of SMEs, it has been found that the main characteristics of the development of SMEs in China are mainly manifested in the following aspects:

\section{A. A Large Number and Wide Distribution}

According to the statistics of the State Administration for Industry and Commerce, there were 4.439 million newly registered enterprises in 2015, an increase of $21.6 \%$ over 2014 $96 \%$ of these newly registered enterprises are small and micro enterprises. According to the National Survey of 100 counties and small and micro enterprises in the National Administration for Industry and Commerce, the enterprises surveyed in the first quarter of 2016 were newly established small and micro enterprises in the first quarter of 2015 [3].The analysis of 7,362 valid questionnaires shows that, from an

*Corresponding author 
industry perspective, the rate of opening of the transportation warehousing industry, agriculture, forestry, animal husbandry and fishery, and accommodation and catering industries ranks the top three, which are $76.7 \%, 74.9 \%$ and $74.2 \%$ respectively. This survey shows that the operating areas of SMEs in China are continuously expanding and the operating structure has been continuously optimized. China's SMEs not only exhibit extensive features in the distribution of their industries, but also are geographically distributed. SMEs are distributed in various regions of the East, Central and West of China in various degrees of intensity [4].

\section{B. The Coexistence of the Characteristics of Individual Weakness and Overall Strength in SMEs in China}

SMEs, the economic group, play an important role in economic life, but also have their own development inadequacies. Individual weakness refers to the fact that for most SMEs in China, they are not able to occupy an advantageous position in the economic market due to the small scale of their own operations. In addition, due to rising prices, increasing labor costs, and high house prices, rents have doubled in recent years [5]. The pressure for the survival of SMEs has soared. In addition, managers of small and mediumsized enterprises in China often have deficiencies in decisionmaking operations and company management, which, to a certain extent, increases the operational risk for SMEs. The overall strength means that SMEs have played an important role without exception in the economic life of countries around the world. For example, in terms of employment, as can be seen from Table 1-1: In 2014, the number of employees participating in the annual statistical report of the State Administration of Industry and Commerce, the number of SMEs employed was $1,084.83$ million, accounting for $47.94 \%$ of the total number of employees in the annual report, compared with the number of employees in the same period of 2013 Increased by $1.57 \%$.

TABLE I. EMPLOYMENT CONTRIBUTION OF SMES IN 2013 AND 2014

\begin{tabular}{|c|c|c|c|}
\hline $\begin{array}{l}\text { Ann } \\
\text { ual } \\
\text { report } \\
\text { year }\end{array}$ & \begin{tabular}{l}
\multicolumn{2}{c}{ Annual } \\
report Total \\
number of \\
enterprises \\
\multicolumn{1}{c}{ (ten } \\
thousand \\
people)
\end{tabular} & $\begin{array}{l}\text { Total number } \\
\text { of SMEs } \\
\text { (ten thousand } \\
\text { people) }\end{array}$ & $\begin{array}{l}\text { The } \\
\text { proportion of } \\
\text { SMEs in the } \\
\text { industry }\end{array}$ \\
\hline 2013 & 21332.48 & 9891.08 & $46.37 \%$ \\
\hline 2014 & 22612.10 & 10840.83 & $47.94 \%$ \\
\hline
\end{tabular}

SMEs are important carriers for absorbing all kinds of entrepreneurial talents, and they have played an important role in providing employment opportunities for job-seekers and thus easing employment pressure in China. The solution to employment problems is conducive to maintaining social stability. It is these characteristics that determine our country and government must pay attention to the development of SMEs.

\section{Diversification of Organizational Forms or Legal Forms}

With the continuous development of our country's market economy, our country's economic system is also continuously developing and improving. Our country's small and mediumsized enterprises' organizational forms show a diversified state of affairs, which can be established by the state or operated by individuals or foreign investors[6].At present, most small and medium-sized enterprises in China are entrepreneurial and self-employed.

\section{Simple Management Level Structure}

Most small and medium-sized enterprises in China are entrepreneurial organizational structures. Generally, they adopt a limited liability company system. The number of shareholders is generally less than 10 persons. Compared with larger companies, the decision-making power of China's SMEs is mostly concentrated in the hands of individual people. Therefore, the management level is often relatively simple. Although a simple management-level structure is prone to mistakes in making decisions, it is also easy to make timely decisions based on market economic conditions, and information transmission is more timely.

\section{OVERVIEW OF FINANCING OF CHINA'S SMES}

Corporate financing refers to an economic activity in which the company raises the funds required for production and operation through certain channels and methods according to its own production and operation status and capital utilization situation, combined with the company's future operation and development strategy.

\section{A. Indirect Financing is Still the Main Route for SME Financing}

According to a survey conducted by the People's Bank of China, the increase in the size of social financing in 2015 was 15.41 trillion yuan, of which RMB loans to the real economy accounted for $73.1 \%$ of the social financing scale in the same period, an increase of 11.3 trillion yuan over 2014, among which the national banking sector The balance of microenterprise loans of financial institutions was 23.46 trillion yuan, accounting for $23.90 \%$ of the total loan balance. This shows that bank loans are still the main channel for the financing of SMEs in China.

\section{1) Using bank loans as the main financing method}

In recent years, China's major banking financial institutions have set up SME financial services franchised institutions targeting the small and medium-sized enterprises (SMEs). Each bank has developed a variety of SME credit products and services based on its own operating characteristics. Loans provide professional and effective services to expand the SME credit market.

Take the Industrial and Commercial Bank of China as an example. According to the annual report of the Industrial and Commercial Bank of China: In 2011, ICBC SMEs grew by $37.4 \%$, and new loans far exceeded 300 billion yuan; in 2012, new loans for small and medium-sized enterprises accounted for ICBC's increase in loans. In $89 \%$ of the volume, the 
balance of small and medium-sized (micro) corporate loans accounted for $72 \%$ of the company's loan balance; in 2013, the financial services for SMEs continued to be improved; the SME loan balance was 1.87 trillion yuan; in 2014, the balance of SME loans was 4.53 trillion yuan, of which, The balance of loans for medium-sized enterprises was 2.80 trillion yuan, and that for small and micro enterprises was 1.72 trillion yuan. In 2015, the net increase in loans for small and micro enterprises was 161.7 billion yuan, an increase of $9.4 \%$. This shows that commercial banks are also committed to solving SME financing problems.
2) Using small and medium-sized financial institutions as major financing institutions

According to statistics from the China Banking Regulatory Commission, as of the end of December 2015, the total assets of large commercial banks in China were 73.6694 trillion yuan, accounting for $37.9 \%$ of banking financial institutions, sharebased commercial banks accounting for $18.8 \%$, and city commercial banks accounting for $13.2 \%$. Other financial institutions accounted for $18.3 \%$.

TABLE II. BANK LOANS FOR SMALL AND MICRO ENTERPRISES IN 2015

Unit: 100 million yuan

\begin{tabular}{|c|c|c|c|c|c|c|}
\hline project & & & & 015 & & \\
\hline date & $\begin{array}{l}\text { First } \\
\text { quarter }\end{array}$ & $\begin{array}{l}\text { Second } \\
\text { quarter }\end{array}$ & $\begin{array}{c}\text { third } \\
\text { quarter }\end{array}$ & $\begin{array}{l}\text { Fourth } \\
\text { quarter }\end{array}$ & total & Accounting \\
\hline $\begin{array}{c}\text { Total Banking } \\
\text { Financial Institutions }\end{array}$ & 214132 & 220493 & 225427 & 234598 & 894650 & $100 \%$ \\
\hline $\begin{array}{l}\text { Including: state- } \\
\text { owned commercial } \\
\text { banks }\end{array}$ & 55803 & 57059 & 57926 & 60195 & 230983 & $25.82 \%$ \\
\hline $\begin{array}{c}\text { Joint-stock } \\
\text { commercial bank }\end{array}$ & 36435 & 36434 & 36041 & 38246 & 147156 & $16.45 \%$ \\
\hline $\begin{array}{l}\text { city Commercial } \\
\text { Bank }\end{array}$ & 32076 & 34053 & 35614 & 37214 & 138957 & $15.53 \%$ \\
\hline $\begin{array}{l}\text { Rural commercial } \\
\text { bank }\end{array}$ & 33039 & 34931 & 36474 & 39230 & 143674 & $16.06 \%$ \\
\hline
\end{tabular}

From the above data, it can be seen that although the ratio of joint-stock commercial banks, city commercial banks and rural commercial banks to SMEs is lower than that of stateowned commercial banks, this is proportional to the proportion of the assets of financial institutions in banking financial institutions.

\section{3) The private lending market is also more active}

The private lending market is active because some small and medium-sized enterprises still find it difficult to obtain financial support from commercial banks. In addition, compared with the complicated procedures for the loan thresholds of China's commercial banks, the high interest rates on loans, and the difficulties in guarantees, private lending operations are simple and sensitive [7]. Rich in resources. However, the lending rate in the private lending market is usually higher, and it is even four times higher than the bank loan interest rate during the same period, which puts more burden on SMEs.

\section{4) Limited direct support to SMEs}

Direct financing means that fund demanders are financing by issuing stocks or bonds. The direct financing methods for SMEs mainly include equity financing and debt financing.

In terms of equity financing, the Chinese government requires very strict regulations, and it requires a minimum of guaranteed profitability for listed companies. In addition, it requires a sound financial management system and a standardized corporate governance mechanism. For SMEs in the early stages of their businesses in China, both the profitability and other aspects are difficult to meet the requirements of the state for listed companies. Since the threshold for the listing of China's SME stocks is too high, this means that for most SMEs in China, there is no way to easily obtain the required funds through equity financing [8].Although the country has opened three new boards in the stock market since 2013, it has indeed opened the door for SME financing to some extent. However, the weak foundation of most SMEs, coupled with the lack of understanding of the capital market by most entrepreneurs, does not make good use of this market [9].On the other hand,

Since GEM is still in its infancy in China, there are still deficiencies that can only alleviate SME financing problems to some extent, and it is difficult to fundamentally solve the problem of financing difficulties for SMEs.

Debt financing is the act of forming a bond and debt relationship through the issuance of bonds. As the state-tobusiness bond issuance management model is "scale control, centralized management, and graded approval", and SMEs often fail to meet the requirements for bond issuance, coupled with the development of the stock market and the bank credit 
market, China The development of the corporate bond market is far behind [10].Therefore, it is almost impossible for SMEs to raise funds through bonds.

\section{CONCLUSION}

All in all, in the rapid development of SMEs today, we can not only ignore the contribution of SMEs to our country's social progress and economic development, but also make efforts for the further development and expansion of SME groups, in addition to the government and SMEs themselves. The social financing institutions and venture capital companies should also facilitate the financing of SMEs so as to help small and medium-sized enterprises to overcome the bottleneck of development and further play their pillar role in the national economy. The financing difficulties of SMEs seem to be a few superficial problems. In fact, there are loopholes in the provision of resource management. If we can give our companies a little bit of easing, SMEs will get better financing results. The only way out is for SMEs to strengthen their own technological advancement, actively develop the market and create a good reputation. In addition, government policies need to be changed. The government is more inclined to SMEs in the formulation of policies.

Finally, commercial banks need to increase financial services for SMEs so that they can effectively solve the problem of financing difficulties for SMEs under the conditions of market economy.

\section{ACKNOWLEDGEMENT}

I would like to express my gratitude to all those who helped me during the writing of this thesis. I gratefully acknowledge the help of my supervisor, Professor Zou Zaijin, who has offered me valuable suggestions in the academic studies. In the preparation of the thesis, he has spent much time reading through each draft and provided me with inspiring advice. Without his patient instruction, insightful criticism and expert guidance, the completion of this thesis would not have been possible.Secondly, thanks to my classmates for their help. During the writing of the thesis, my classmates always eagerly helped me and shared the data information I needed. We exchanged their own writing experience from time to time. This brought me the perfect paper for me a lot of ideas.

\section{REFERENCE}

[1] Berger.A.N,Udell.G.F.Relationship leading and lines of credit in small firm finance.[J].Journal of business,vol.68,1995.

[2] Yin Jianrong. Discussion on SME Financing Problem [J]. Finance and Accounting, 2015, 8:18-19.

[3] Du Qingxia. Analysis of financing strategy for small and mediumsized enterprises based on microfinance companies [J]. Chinese Market, 2015, 40: 95-99.

[4] Zhang Yongli. Try to analyze the direct financing of SMEs [J]. Financial Markets, 2016, 4: 56-57.

[5] Wang Man, Zhang Miao. Financing characteristics and countermeasures of SMEs under the new normal[J]. Economic Review, 2016,2:56-59.

[6] Wang Tao. Microfinance: A New Path for SME Financing [J]. Modern Commerce and Industry, 2016, 8: 98-99.

[7] Chen Fang, Li Jinping. The Impact of Small Loan Companies on SME Financing: An Empirical Analysis of 61 Microfinance Companies and Their Loans [J]. Financial Review, 2012, 6: 92-104.

[8] Niu Fulian. Where are the difficulties in the development of small, medium and micro enterprises? [N]. China Economic Times, 20158-7(11)

[9] Lu Wei. How to solve the problem of financing for SMEs [N]. Financial Times, 2011-12-20 (12).

[10] Xu Jing. Research on the problems in the development of microcredit companies in China and their countermeasures[J]. Modern Communication, 2016, 2:51-53. 